\title{
Vigtig bog om køn i sygepleje går skævt i byen
}

Ben Farid Røjgaard Nielsen:

\section{Køn i sygeplejepraksis}

Forlaget Samfundslitteratur, 2018. 114 sider. Pris: 119,95 kr.

"Køn i sygeplejerskepraksis" er den første i en ny serie rettet mod sygeplejerskestuderende og er tiltænkt at give de studerende et "let tilgængeligt overblik" indenfor en række temaer, i dette tilfælde køn. Ulighed i sundhed med baggrund i køn gør dette til en særdeles tiltrængt bog, men at formidle et så stort og mangefacetteret område som køn og sundhed på små 100 sider er lidt af en opgave. Personligt havde jeg nok afvist dette som muligt.

Bogen er opbygget med et kort introducerende kapitel om kønsforskelle i reaktion på sygdom, og en række korte kapitler om specifikke sygdomsområder og dertil studierepeterende spørgsmål. Bogen afsluttes med en perspektiverende del samt konkrete anbefalinger og refleksioner. Helt som forlaget lægger op til er formatet kort, sproget er lægmandssprog uden fagspecifikke termer, og de studierepeterende spørgsmål meget enkle. Bogen er således studierelevant litteratur men i den lette ende af genren.

Farid Nielsen skriver i forordet at det udfordrende ved at skrive en bog om køn skyldes omdrejningspunktet biologi/kultur og i hvilken grad køn er formet heraf: "I denne bog er svaret et både-og. Det ligger som en helt grundlæggende præmis i bogen, at mennesket har et biologisk køn såvel som et socialt køn. Lige så umuligt det er at adskille plat fra krone på en mønt, lige så lidt giver det mening at adskille det biologiske $k ø n$ fra det sociale køn. Patienter må derfor ses som biologisk-sociale væsener, der har et biologisk køn men også et socialt køn, der ændrer sig, i takt med at samfundet ændrer sig" (s.9). Det sociale køn ses altså dels adskilt fra det biologiske, men også som modsætning hertil ved at være formbart og ikke-statisk. Underforstået er det biologiske køn altså fixeret og upåvirkeligt af den sociale og kulturelle kontekst det indgår i. Det ér bare, og bogens budskab videreformidler så, at der dertil findes et socialt og kulturelt påvirkeligt køn som man er $n \emptyset d t$ til at medtænke i sygeplejen. Det er i sin insisteren på denne grundpræmis for bogen, at Farid Nielsen i mine øjne går, om ikke galt, så i hvert fald skævt, i byen. For kan man egentlig med god samvittighed foretage en sådan opdeling? Kan man friholde biologien, og dermed det 'biologiske køn', 
fra en kulturel påvirkelighed? Historisk har netop (kvinder og minoriteters) kroppe og 'biologi' altid stået i centrum for magtens styringsmekanismer, og en så rigid opdeling af hvad der er biologi og hvad der er kultur, ser jeg helt enkelt ikke belæg for at hævde i dag. Som minimum kunne forfatteren have foretaget en tydelig definition af 'biologisk køn'. At der er fysiologiske forskelle bundet til kroppe med bestemte kønstegn er jo både reelt og relevant, mens det at antage at folk har et egentligt biologisk køn de ikke kan rende fra og at det findes en egentlig statisk begribelig biologi, ikke er det. Ved en klar definition kunne man således have åbnet for, at også biologi (og den dertil knyttede forskning) ligeledes er genstand for skiftende fortolkninger over tid og ikke blot den urørlige pendant til det sociale.

Grundlæggende kan man spørge om det, at ulighed og forskelsbehandling bunder i en binær kønsforståelse indenfor rammerne af et patriarkalsk samfund med stor kønsulighed, også bør lede til løsninger indenfor samme ramme således som forfatteren lægger op til her? Bogen udpeger hvordan køn, og det ikke at medtænke det i sin sygeplejefaglige tilgang, leder til under- og fejlbehandling, giver ringere udkomme af behandlingen og i nogle tilfælde marginaliserer patienter som undlader at opsøge hjælp i tide. Men bogen reproducerer også samtidig en række kønsstereotyper og det skaber et rodet indtryk, hvor man som læser efterlades forvirret.

Der formidles forskning som viser at mænd og kvinder har forskellige reaktioner og copingmekanismer på hv. Sygdom og rehabilitering og at dette medfører en kønsbetinget ulighed i sundhed og behandling. Som Iøsning løfter bogen at dette bør imødegås ved at medtænke køn i behandlingen. Der gives så forskellige eksempler på hvordan dette kan gøres, men nogle af disse løsningsforslag savner helt enkelt en argumentation for hvorfor denne løsning skal bindes op på køn. Et eksempel er i afsnittet om apopleksi (neurologiske senfølger efter hjerneskade), hvor det indledende nævnes at der ikke findes "meget nyere forskning" om mænds oplevelser heraf. Derefter præsenteres Sundhedsstyrelsens anbefalinger om kønsspecifikke rehabiliteringsaktiviteter, hvoraf systematiske præstations- og funktionsmålinger "Køn i sygeplejerskepraksis" er den første i en ny serie rettet mod sygeplejerskestuderende og er tiltænkt at give de studerende et "let tilgængeligt overblik" indenfor en række temaer, i dette tilfælde $k \emptyset n$. Ulighed i sundhed med baggrund i $k ø n$ gør dette til en særdeles tiltrængt bog, men at formidle et så stort og mangefacetteret område som køn og sundhed på små 100 sider er lidt af en opgave. Personligt havde jeg nok afvist dette som muligt.

Bogen er opbygget med et kort introducerende kapitel om kønsforskelle i reaktion på sygdom, og en række korte kapitler om specifikke sygdomsområder og dertil studierepeterende spørgsmål. Bogen afsluttes med en perspektiverende del samt konkrete anbefalinger og refleksioner. Helt som forlaget lægger op til er formatet kort, sproget er lægmandssprog uden fagspecifikke termer, og de studierepeterende spørgsmål meget enkle. Bogen er således studierelevant litteratur men i den lette ende af genren.

Farid Nielsen skriver i forordet at det udfordrende ved at skrive en bog om køn skyldes omdrejningspunktet biologi/kultur og i hvilken grad køn er formet heraf: "I denne bog er svaret et både-og. Det ligger som en helt grundlæggende præmis i bogen, at mennesket har et biologisk køn såvel som et socialt køn. Lige så umuligt det er at adskille plat fra krone på en mønt, lige så lidt giver det mening at adskille det biologiske $k ø n$ fra det sociale $k \emptyset n$. Patienter må derfor ses som biologisk-sociale væsener, der har et biologisk køn men også et socialt køn, der ændrer sig, i takt med at samfundet ændrer sig" (s.9). Det sociale køn ses altså dels adskilt fra det biologiske, men også som modsætning hertil ved at være formbart og ikke-statisk. Underforstået er det biologiske køn altså fixeret og upåvirkeligt af den sociale og kulturelle kontekst det indgår i. Det ér bare, og bogens budskab videreformidler så, at der dertil findes et socialt og kulturelt påvirkeligt køn som man er nødt til at medtænke i sygeplejen. Det er i sin insisteren på denne grundpræmis for bogen, at Farid Nielsen i mine øjne går, om ikke galt, så i hvert fald skævt, i byen. For kan man egentlig med god samvittighed foretage en sådan opdeling? Kan man friholde biologien, og dermed det 'biologiske køn', 
fra en kulturel påvirkelighed? Historisk har netop (kvinder og minoriteters) kroppe og 'biologi' altid stået i centrum for magtens styringsmekanismer, og en så rigid opdeling af hvad der er biologi og hvad der er kultur, ser jeg helt enkelt ikke belæg for at hævde i dag. Som minimum kunne forfatteren have foretaget en tydelig definition af 'biologisk køn'. At der er fysiologiske forskelle bundet til kroppe med bestemte kønstegn er jo både reelt og relevant, mens det at antage at folk har et egentligt biologisk køn de ikke kan rende fra og at det findes en egentlig statisk begribelig biologi, ikke er det. Ved en klar definition kunne man således have åbnet for, at også biologi (og den dertil knyttede forskning) ligeledes er genstand for skiftende fortolkninger over tid og ikke blot den urørlige pendant til det sociale.

Grundlæggende kan man spørge om det, at ulighed og forskelsbehandling bunder i en binær kønsforståelse indenfor rammerne af et patriarkalsk samfund med stor kønsulighed, også bør lede til løsninger indenfor samme ramme således som forfatteren lægger op til her? Bogen udpeger hvordan køn, og det ikke at medtænke det i sin sygeplejefaglige tilgang, leder til under- og fejlbehandling, giver ringere udkomme af behandlingen og i nogle tilfælde marginaliserer patienter som undlader at opsøge hjælp i tide. Men bogen reproducerer også samtidig en række kønsstereotyper og det skaber et rodet indtryk, hvor man som læser efterlades forvirret.

Der formidles forskning som viser at mænd og kvinder har forskellige reaktioner og copingmekanismer på hv. Sygdom og rehabilitering og at dette medfører en kønsbetinget ulighed i sundhed og behandling. Som løsning løfter bogen at dette bør imødegås ved at medtænke køn i behandlingen. Der gives så forskellige eksempler på hvordan dette kan gøres, men nogle af disse løsningsforslag savner helt enkelt en argumentation for hvorfor denne løsning skal bindes op på køn. Et eksempel er i afsnittet om apopleksi (neurologiske senfølger efter hjerneskade), hvor det indledende nævnes at der ikke findes "meget nyere forskning" om mænds oplevelser heraf. Derefter præsenteres Sundhedsstyrelsens anbefalinger om kønsspecifikke rehabiliteringsaktiviteter, hvoraf systematiske præstations- og funktionsmålinger anbefales særligt til mænd (såkaldt 'benchmarking'). Dette skulle angiveligt skabe en motivation og en meningsfuldhed som holder dem til ilden under genoptræning. Denne pointe afrundes så med sætningen: "Gubrium og kollegaer (2003) pointerer, at kvinder formodentligt også kan profitere af benchmarking, men at fænomenet især er knyttet til mænd"(s. 63). Hvorfor det især er det, hvorfor det formodentlig også er det for kvinder, og hvorfor det så fortsat benyttes som en kønsspecifik aktivitet for mænd, står således åbent. Flere af kapitlerne har således store huller i argumentation og dette sætter et spørgsmålstegn ved både bogens tilgang og ikke mindst en del af den refererede forskning.

Sex og intimitet er både en central del af et bredere sundhedsbillede, men også af menneskets kønsidentitet, og når emnet alene bringes op i kapitlet om LGBTQ personer bliver det et kedeligt klassisk greb: Heteroseksualitet ér den uproblematiserede norm som bare ér, mens det som afviger sættes under lup. Der præsenteres forskning i lgbtq personers (mangel på) sundhed, ligesom det meget relevante begreb minioritetsstress introduceres, men den veldokumenterede uheldige rolle som sundhedspersonalet spiller heri, nævnes knapt. Samme greb ses i kapitlet om trans* som fremstår med begrænset forståelse for feltet og få primære referencer. Af alt hvad man kunne have grebet fat i om transpersoners sundhed, så bruges der en knap en halv side på "navneskiftet" hvor vi f.eks oplyses om at man kan hedde både Kamel, Sok, og Altan. Det fremstår helt enkelt useriøst og en anelse latterligg ørende.

På trods af enkelte gode kapitler og glimtvis interessante reflektioner, så fremstår bogen overfladisk og visse steder decideret problematisk, ligesom det normkritiske blik glimrer ved sit totale fravær. Havde siderne i stedet været brugt på at udfolde et bredere og mere nuanceret teoretisk blik på køn (og seksualitet), så havde det styrket bogens faglige tyngde. Fra forlagets side skulle man måske have udvalgt et enkelt sygeplejefagligt område og så derfra have trukket nogle generelle tråde derfra omkring $k ø n$ og seksualitet. I al sin begrænsning havde dette ydet emnet køn i 
sygepleje langt større retfærdighed. Som feministisk jordemoder og sexolog ser jeg derfor bogen som et godt og tiltrængt initiativ, der desværre ikke får fulgt formålet helt til dørs og hvor man godt kunne have $\emptyset$ nsket sig langt større ambitioner fra forlagets side. Det vedstår fortsat at få udgivet litteratur der for alvor motiverer sundhedsuddannelserne til at arbejde bevidst og kritisk med fagligheden i forhold til køn, krop og seksualitet.

CAMILLA TVED, jordemoder og sexolog med normkritisk og feministisk udgangspunkt. Har netop færdiggjort en master i sexologi ved Malmø Universitet om queerpersoner i fertilitetsbehandling. Er privatpraktiserende i København, og er desuden underviser og skribent 